\title{
Tinjauan Manajemen Risiko Bidang Kesehatan dan Keselamatan Kerja pada Proyek Konstruksi Bekas Daerah Pembuangan Sambirejo di Masa Pandemi Covid-19
}

\author{
ADEN FIRDAUS, HAZAIRIN, GHEA PUSPITA PARTADISASTRA \\ Program Studi Teknik Sipil, Institut Teknologi Nasional Bandung, Indonesia \\ Email: adenfirdaus@itenas.ac.id
}

\begin{abstract}
ABSTRAK
Proyek konstruksi merupakan penyumbang angka kasus kecelakaan kerja terbanyak di Indonesia. Pandemi Covid-19 mempengaruhi cara kerja di bidang konstruksi. Banyak perusahaan yang telah memiliki sintem manajemen K3, namun sistem manajemen $K 3$ tersebut belum berbasis manajemen risiko. Tujuan utama dari manajemen risiko adalah mengukur, mengidentifikasi, memetakan, mengembangkan alternatif penanganan risiko serta mendorong tingkat manajemen untuk proaktif mengurangi risiko kerugian yang diakibatkan oleh kecelakaan kerja. Data yang diambil untuk penelitian ini menggunakan instrument kuesioner. Dari hasil penelitian pada proyek Pembangunan bekas daerah pembuangan sambirejo ditemukan 92 variabel bahaya, yang terdiri dari 2 risiko tinggi, 34 risiko rendah, dan 56 risiko sedang. Resiko tertinggi adalah penyebaran virus Covid-19.
\end{abstract}

Kata kunci: manajemen risiko, konstruksi, K3, Covid-19

\begin{abstract}
Construction projects are the largest contributor to the number of work accident cases in Indonesia. The Covid-19 pandemic has affected the way construction works. Many companies already have an OHS management system, but the OHS management system is not yet based on risk management. The main purpose of risk management is to measure, identify, map, develop alternative risk management and encourage management levels to proactively reduce the risk of losses caused by work accidents. The data taken for this study used a questionnaire instrument. From the results of research on the development project of the former Sambirejo dumping area, 92 hazard variables were found, consisting of 2 high risk, 34 low risk, and 56 moderate risk. The highest risk is the spread of the Covid-19 virus.
\end{abstract}

Keywords: risk management, construction, OHS, Covid-19 


\section{PENDAHULUAN}

Menurut Badan Penyelenggara Jamiman Sosial (BPJS) tahun 2018 angka kecelakaan kerja di bidang konstruksi mencapai 173.105 kasus kecelakaan kerja. Jumlah kasus kecelakaan kerja yang di tahun 2018 ini melonjak sekitar 29\% dari tahun sebelumnya (2017). Angka kasus kecelakaan kerja masih cukup tinggi, masih banyak perusahaan yang gagal menerapkan SMK3 dengan baik dan efektif. Di Indonesia, kasus positif Covid-19 pertama kali dideteksi pada tanggal 2 Maret 2020 (Wikipedia). Semenjak saat itu pemerintah Indonesia menetapkan kondisi darurat dan beberapa peraturan lainnya yang mempengaruhi cara kerja di berbagai bidang, termasuk bidang konstruksi. Dalam mencapai penerapan dan sistem manajemen keselamatan dan kesehatan kerja (K3) yang baik maka diperlukan peran dari berbagai pihak dalam pengendalian risiko risiko yang terjadi pada proyek konstruksi. Pengendalian risiko ini meliputi manajemen konstruksi. Pembangunan Proyek Pembangunan Bekas Daerah Pembuangan Sambirejo merupakan pekerjaan konstruksi yang memiliki tingkat kerumitan pekerjaan yang sedang. Penggunaan alat berat dan metode pelaksanaan yang rumit dapat menimbulkan risiko risko kecelakaan pada pekerjaan tersebut. Maka dari itu atas permasalahan tersebut diperlukan pengendalian risiko keselamatan dan kesehatan kerja (K3).

\section{TINJAUAN PUSTAKA}

\subsection{Manajemen Risiko dalam Sistem Manajemen K3}

Menurut Soehatman Ramli tahun 2010 Manejemen Risiko sangat erat hubungannnya dengan K3 (Gambar 1). Aspek K3 timbul akibat adanya risiko yang mengancam keselamatan pekerja, lingkungan kerja, dan sarana sehingga diperlukan pengelolaan yang baik. Sedangkan keberadaan risiko dalam kegiatan perusahaan mendorong perlunya upaya keselamatan untuk mengendalikan risiko yang ada. Dengan demikian, di dalam berbagai sistem manajemen $\mathrm{K} 3$ selalu menempatkan aspek manajemen risiko sebagai landasan utama penerapan K3 dalam perusahaan.

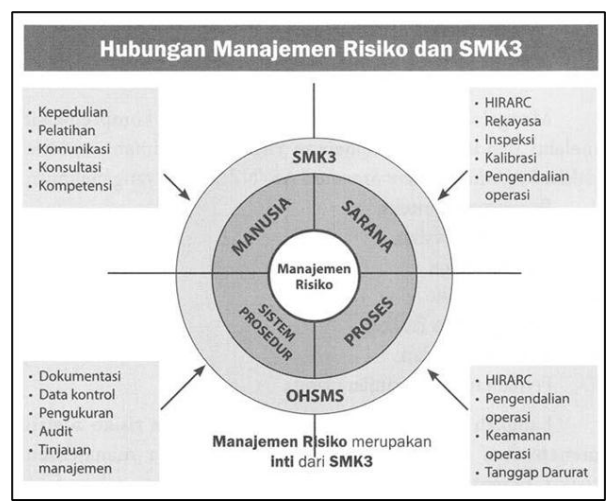

Gambar 1. Hubungan manajemen risiko dan sistem manajemen K3 (Sumber: Ramli, 2010)

\subsection{Identifikasi Bahaya}

Pengenalan bahaya adalah tahap awal yang penting dalam pengembangan manajemen risiko K3 di lingkungan proyek terutama di bidang konstruksi. Ini merupakan langkah sistematis untuk mengetahui adanya bahaya dalam aktivitas pekerjaan proyek dan organisasi pada umumnya. Identifikasi bahaya juga merupakan dasar dari manajemen risiko. Tanpa melakukan identifikasi bahaya, maka akan sulit untuk melakukan pengelolaan risiko secara cepat dan tepat. Untuk mengidentifikasi bahaya diperlukan langkah yang proaktif dalam melihat bahaya sebelum bahaya tersebut terjadi atau berdampak yang merugikan. 


\subsection{Analisis dan Penilaian Risiko}

Penilaian risiko yang sering digunakan mencakup dua tahapan proses yaitu menganalisis risiko dan mengevaluasi risiko. Analisis risiko pada dasarnya bertujuan untuk menentukan besarnya suatu risiko yang merupakan kombinasi antara kemungkinan (likelihood) terjadinya dan keparahan bila risiko tersebut muncul dan terjadi (severity atau consequences).

a. Analisis Risiko dengan Teknik Kualitatif

Matriks risiko digunakan sebagai metoda kualitatif yang menggambarkan tingkat kemungkinan dan keparahan suatu kejadian yang dinyatakan dalam bentuk rentang dari risiko paling rendah sampai risiko tertinggi seperti terlihat pada Tabel 1 dan Tabel 2.

Tabel 1. Skala Ukuran Semi Kuantitatif dari Likelihood Menurut AS/NZS 4360

\begin{tabular}{ccc}
\hline Level & Kriteria & Penjelasan \\
\hline 1 & Almost Certain & Keadaan hampir pasti \\
\hline 2 & Likely & Sangat mungkin terjadi \\
\hline 3 & Possible & Mungkin terjadi \\
\hline 4 & Unlikely & Kemungkinan jarang terjadi \\
\hline 5 & Rare & Hampir tidak pernah \\
\hline Sumber: & Risk Management AS/NZS 4360
\end{tabular}

Tabel 2. Skala Ukuran Semi Kuantatif dari Saverity Menurut AS/NZS 4360:2004

\begin{tabular}{ccc}
\hline Level & Descriptor & Uraian \\
\hline 1 & Insignifant & Kerugian finansial kecil dan tidak ada cedera \\
\hline 2 & Minor & Kerugian finansial sedang dan cedera ringan \\
\hline 3 & Moderate & Kerugian finansial besar, cedera sedang dan perlu penangan medis \\
\hline 4 & Major & Kerugian finansial besar, gangguan produksi, cedera berat lebih dari satu orang \\
\hline 5 & Catastrophic & Kerugian finansial besar, kecelakaan fatal, dampak luas dan panjang, seluruh kegiatan berhenti \\
\hline & & Sumber: Risk Management AS/NZS 4360
\end{tabular}

b. Peringkat Risiko

Peringkat risiko adalah matriks risiko yang membandingkan antara kemungkinan dan keparahan. Penilaian risiko adalah risiko yang diformulasikan sebagai fungsi dari kemungkinan terjadi (likelihood) dan dampak (consequences), atau indeks risiko sama dengan perkalian kemungkinan dengan dampak seperti tertera pada Persamaan 1 dan Tabel 3 berikut (AS/NZS 4360 : 2004 Risk Management).

$$
\text { Indeks Risiko }(\text { Risk })=\text { Likelihood } \times \text { Consequences }
$$

Tabel 3. Nilai Indeks Risiko Menurut AS/NZS 4360:2004

\begin{tabular}{ccc}
\hline Nilai Risiko & Kategori Risiko & Keterangan \\
\hline $1-4$ & $\mathrm{~L}$ & Low \\
\hline $4-9$ & $\mathrm{M}$ & Moderate \\
\hline $9-17$ & $\mathrm{H}$ & High \\
\hline $17-25$ & $\mathrm{VH}$ & Very High \\
\hline & Sumber: AS/NZS 4360 : 2004
\end{tabular}

keterangan:

VH: Very High Risk = Risiko sangat tinggi dan/ atau tidak dapat ditelorenasi. Perlu penanganan seketika.

$\mathrm{H}$ : High Risk = Risiko tinggi dan perlu perhatian manajemen untuk ditangani segera.

M : Moderate Risk = Risiko sedang dan perlu langkah penangan dari manajemen.

L : Low Risk = Risiko rendah dan perlu pengangan sengan SOP biasa. 


\section{METODE PENELITIAN}

Pada penelitian ini, metode penelitian dilakukan dengan cara pengambilan data dan pengamatan langsung di lapangan. Studi kasus ini berupa metode semi kuantitatif. Teknik pengumpulan sampel yaitu dengan teknik purposive sampling. Sampel yang diambil tidak berdasarkan acak, daerah atau strata, melainkan berdasarkan atas adanya pertimbangan yang berfokus pada tujuan tertentu (Arikunto, 2006). Dari pengertian pengambilan sampel maka pada penelitian ini sampel yang digunakan berjumlah 10 orang yang meliputi staff dari pihak kontraktor. Tahapan selanjutnya yaitu uji validitas dan realibitas dari hasil pengambilan data, dengan menggunakan Korelasi Bivariate Pearson (Produk Momen Pearson). Jika r hitung $\geq r$ tabel (uji 2 sisi dengan sig. 0,06) maka instrumen atau item-item pertanyaan dianggap mempunyai korelasi yang tinggi terhadap skor total dan dinyatakan valid. Nilai reliabilitas minimum yang diambil adalah 0,600 . Pengujian reliabilitas instrumen pada penelitian ini menggunakan rumus Alpha Cronbach karena instrumen penelitian yang digunakan berbentuk angket dan skala bertingkat. Pengolahan data yang dilakukan yaitu dengan cara mengidentifikasi bahaya yang ada di lapangan dengan teknik wawancara kepada Safety Officer, kemudian dilakukan penilaian risiko dengan mencari nilai Indeks Risiko. Nilai tersebut dapat menentukan kategori bahaya yang ditemukan di lapangan.

\section{PEMBAHASAN DAN DISKUSI}

\subsection{Data Profil Responden}

Hasil hasil dari pengumpulan data profile 10 responden akan diuraikan sebagai berikut:

1. Tingkat Pendidikan
a. S1: $80 \%$
b. $\mathrm{S} 2: 10 \%$
c. D3 : $10 \%$

2. Jabatan di Perusahaan sebagai:
a. Project Manager
: 1 orang
b. Safety Officer
: 1 orang
c. Site Manager
: 1 orang
d. Surveyor
: 1 orang
e. Site Engineer
: 3 orang
f. Geomembrane Specialist : 1 orang
g. Civil Work Supervisor : 1 orang
h. Landscaping Supervisor : 1 orang

3. Usia Responden sebanyak 3 orang atau $30 \%$ dari responden memiliki usia $\leq 25$ tahun, sebanyak 4 orang atau $40 \%$ memiiki usia $26 \geq X \leq 35$ tahun dan sebanyak 3 orang memiliki usia $\geq 36$ tahun.

4. Pengalaman bekerja sebanyak 4 orang atau $40 \%$ memiliki waktu pengalaman kerja $>5$ tahun dan sebanyak 6 orang atau $60 \%$ memiliki waktu pengaalaman kerja $<5$ tahun.

\subsection{Penilaian Risiko}

Penilaian risiko diformulasikan dari probability dikali dengan concequences, hasil dari nilai tersebut digunakan sebagai pengelompokan kategori risiko berdasarkan nilai indeks risiko dari AS/NZS 4360 : 2004. Rangking risiko dapat dilihat pada Tabel 4 di bawah ini. 
Tabel 5. Hasil Penilaian Risko

\begin{tabular}{|c|c|c|c|c|c|c|}
\hline \multicolumn{3}{|c|}{ Event Resiko } & \multicolumn{3}{|c|}{ Table Perhitungan } & \multirow[b]{2}{*}{ Kategori } \\
\hline \multirow{2}{*}{ Pekerjaan } & \multirow[t]{2}{*}{ No } & \multirow[t]{2}{*}{ Variable Resiko } & $\begin{array}{c}\text { Nilai Rata } \\
\text { Rata }\end{array}$ & $\begin{array}{c}\text { Nilai Rata } \\
\text { Rata }\end{array}$ & Indeks & \\
\hline & & & Frekuensi & Keparahan & Resiko & Resiko \\
\hline \multicolumn{7}{|c|}{ Pekerjaan Persiapan } \\
\hline \multirow{2}{*}{$\begin{array}{c}\text { Pemeriksaan } \\
\text { Kesehatan; Rapid } \\
\text { Test/PCR }\end{array}$} & 1 & Penyebaran COVID-19 & 3,5 & 4,7 & 16,45 & $\mathrm{H}$ \\
\hline & 2 & Reaktif/ Positif COVID- 19 & 3,6 & 4,5 & 16,2 & H \\
\hline \multicolumn{7}{|c|}{$\begin{array}{c}\text { Pekerjaan Topografi } \\
\end{array}$} \\
\hline \multirow{3}{*}{$\begin{array}{c}\text { Pengukuran } \\
\text { Polygon/BM, } \\
\text { Pengukuran Baseline, } \\
\text { dan Pengukuran } \\
\text { Existing Area : } \\
\text { Mengukur } \\
\text { menggunakan alat } \\
\text { total station }\end{array}$} & 3 & Terjatuh & 1,4 & 1,5 & 2,1 & $\mathbf{L}$ \\
\hline & 4 & Tergores & 1,4 & 1,5 & 2,1 & $\mathbf{L}$ \\
\hline & 5 & Dehidrasi & 1,5 & 1,5 & 2,25 & $\mathbf{L}$ \\
\hline \multicolumn{7}{|c|}{ Pekerjaan Temporary Facility } \\
\hline \multirow{2}{*}{$\begin{array}{l}\text { Pemadatan tanah } \\
\text { dengan stemper } \\
\text { sesuai penanda }\end{array}$} & 6 & Terjatuh & 1,5 & 2,2 & 3,3 & $\mathbf{L}$ \\
\hline & 7 & Stemper terguling & 1,9 & 2,2 & 4,18 & $\mathbf{M}$ \\
\hline \multirow{3}{*}{ Penggalian Pondasi } & 8 & $\begin{array}{l}\text { Terjatuh akibat lubang } \\
\text { penggalian pondasi }\end{array}$ & 1,5 & 2,1 & 3,15 & $\mathbf{L}$ \\
\hline & 9 & $\begin{array}{c}\text { Tertusuk handtools saat } \\
\text { melakukan penggalian } \\
\text { pondasi }\end{array}$ & 1,9 & 2,4 & 4,56 & $\mathbf{M}$ \\
\hline & 10 & $\begin{array}{l}\text { Tersayat handtools saat } \\
\text { melakukan penggalian }\end{array}$ & 1,9 & 2,4 & 4,56 & M \\
\hline \multirow[b]{2}{*}{ Pengecoran Pondasi } & 11 & Iritasi Kulit & 1,4 & 2,1 & 2,94 & $\mathbf{L}$ \\
\hline & 12 & $\begin{array}{c}\text { Cairan Concrete masuk ke } \\
\text { mata }\end{array}$ & 1,5 & 2,3 & 3,45 & $\mathbf{L}$ \\
\hline \multirow{4}{*}{$\begin{array}{l}\text { Pemasangan } \\
\text { bekisting }\end{array}$} & 13 & $\begin{array}{c}\text { Terpukul oleh alat kerja } \\
\text { yang digunakan }\end{array}$ & 1,4 & 2,4 & 3,36 & $\mathbf{L}$ \\
\hline & 14 & Tersayat alat kerja & 1,4 & 2,2 & 3,08 & $\mathbf{L}$ \\
\hline & 15 & Tertusuk serpihan kayu & 1,4 & 2,3 & 3,22 & $\mathbf{L}$ \\
\hline & 16 & Terjepit material & 1,4 & 2,2 & 3,08 & $\mathbf{L}$ \\
\hline $\begin{array}{l}\text { Pengecoran slab } \\
\text { lantai, ompak dan } \\
\text { pondasi fuel tank }\end{array}$ & 17 & $\begin{array}{c}\text { Terpeleset sekitar area } \\
\text { kerja }\end{array}$ & 1,5 & 1,9 & 2,85 & $\mathbf{L}$ \\
\hline \multirow[t]{2}{*}{$\begin{array}{l}\text { Pemasangan rangka } \\
\text { baja ringan, } \\
\text { pemasangan dinding } \\
\text { prefab, pemasangan } \\
\text { kusen pintu dan } \\
\text { jendela, pemasangan } \\
\text { jendela dan pintu }\end{array}$} & 18 & Terjepit material & 2 & 1,9 & 3,8 & $\mathbf{L}$ \\
\hline & 19 & Tertimpa material kerja & 1,6 & 1,9 & 3,04 & $\mathbf{L}$ \\
\hline \multirow[t]{3}{*}{$\begin{array}{l}\text { Pemasangan rangka } \\
\text { atap \& pemasangan } \\
\text { atap }\end{array}$} & 20 & Terjatuh & 1,8 & 2,8 & 5,04 & $\mathbf{M}$ \\
\hline & 21 & $\begin{array}{c}\text { Tertimpa material atap } \\
\text { atau rangka atap }\end{array}$ & 2,5 & 2,7 & 6,75 & $\mathbf{M}$ \\
\hline & 22 & Tertimpa alat kerja & 1,9 & 2,6 & 4,94 & $\mathbf{M}$ \\
\hline $\begin{array}{c}\text { Pemasangan rangka } \\
\text { kayu \& pemasangan } \\
\text { papan lantai }\end{array}$ & 23 & Terpukul alat kerja & 1,4 & 2,2 & 3,08 & $\mathbf{L}$ \\
\hline \multirow[t]{2}{*}{$\begin{array}{c}\text { Pemasangan dinding } \\
\text { Spandek }\end{array}$} & 24 & Tersayat spandek & 2 & 1,9 & 3,8 & $\mathbf{L}$ \\
\hline & 25 & Tertimpa spandek & 2,3 & 2,2 & 5,06 & $\mathbf{M}$ \\
\hline \multicolumn{7}{|c|}{ Pekerjaan Pembersihan Lahan Area Konstruksi } \\
\hline $\begin{array}{l}\text { Pemasangan rambu } \\
\text { rambu survey }\end{array}$ & 26 & $\begin{array}{c}\text { Terpukul oleh alat kerja } \\
\text { yang digunakan }\end{array}$ & 1,6 & 1,9 & 3,04 & $\mathbf{L}$ \\
\hline
\end{tabular}


Aden Firdaus, Hazairin, Ghea Puspita Partadisastra

Tabel 5. Hasil Penilaian Risko lanjutan

\begin{tabular}{|c|c|c|c|c|c|c|}
\hline \multicolumn{3}{|c|}{ Event Resiko } & \multicolumn{3}{|c|}{ Table Perhitungan } & \multirow[b]{2}{*}{ Kategori } \\
\hline \multirow{2}{*}{ Pekerjaan } & \multirow{2}{*}{ No } & \multirow{2}{*}{ Variable Resiko } & $\begin{array}{l}\text { Nilai Rata } \\
\text { Rata }\end{array}$ & $\begin{array}{l}\text { Nilai Rata } \\
\text { Rata }\end{array}$ & Indeks & \\
\hline & & & Frekuensi & Keparahan & Resiko & Resiko \\
\hline $\begin{array}{l}\text { Penebangan pohon } \\
\text { diameter dengan } \\
\text { gergaji dan parang }\end{array}$ & 27 & Tertimpa pohon & 2,1 & 3,1 & 6,51 & $\mathbf{M}$ \\
\hline $\begin{array}{l}\text { Pengecoran slab } \\
\text { lantai, ompak dan } \\
\text { pondasi fuel tank }\end{array}$ & 28 & Tersayat parang & 2,8 & 3,1 & 8,68 & $\mathbf{M}$ \\
\hline \multirow[t]{2}{*}{$\begin{array}{c}\text { Pengupasan semak } \\
\text { belukar dengan } \\
\text { Dozer }\end{array}$} & 29 & Tertabrak Dozer & 1,6 & 3 & 4,8 & $\mathbf{M}$ \\
\hline & 30 & $\begin{array}{l}\text { Kelongsoran tanah akibat } \\
\text { ketidakstabilan }\end{array}$ & 3 & 3,1 & 9,3 & $\mathbf{M}$ \\
\hline \multirow[t]{3}{*}{$\begin{array}{l}\text { Pembuangan semak } \\
\text { belukar ke stockpile }\end{array}$} & 31 & Tertusuk duri belukar & 1,6 & 1,8 & 2,88 & $\mathbf{L}$ \\
\hline & 32 & Tertabrak truk & 2,7 & 3,4 & 9,18 & M \\
\hline & 33 & Tertimbun stockpile & 2,4 & 3 & 7,2 & $\mathbf{M}$ \\
\hline Mobilisasi Alat Berat & 34 & Kemacetan \& Tabrakan & 1,8 & 2 & 3,6 & $\mathbf{L}$ \\
\hline $\begin{array}{l}\text { Pemasangan dinding } \\
\text { Spandek }\end{array}$ & 35 & Kerusakan fasilitas umum & 3,2 & 1,9 & 6,08 & $\mathbf{M}$ \\
\hline \multirow[t]{3}{*}{ Penurunan Alat Berat } & 36 & Terjatuh & 1,6 & 2,1 & 3,36 & $\mathbf{L}$ \\
\hline & 37 & Terkilir & 1,5 & 2,1 & 3,15 & $\mathbf{L}$ \\
\hline & 38 & Terhantam & 2,7 & 2,5 & 6,75 & $\mathbf{M}$ \\
\hline \multicolumn{7}{|c|}{ Pekerjaan Pembobokan Dinding } \\
\hline \multirow[t]{2}{*}{$\begin{array}{c}\text { Menyiapkan alat jack } \\
\text { hammer }\end{array}$} & 39 & Terjepit alat & 1,3 & 1,8 & 2,34 & $\mathbf{L}$ \\
\hline & 40 & Tersayat & 1,3 & 2,1 & 2,73 & $\mathbf{L}$ \\
\hline \multirow{4}{*}{$\begin{array}{l}\text { Membobok dinding } \\
\text { penahan tanah }\end{array}$} & 41 & Terjatuh & 1,7 & 1,9 & 3,23 & $\mathbf{L}$ \\
\hline & 42 & Tertusuk alat kerja & 1,4 & 2,2 & 3,08 & $\mathbf{L}$ \\
\hline & 43 & Terpental saat membobok & 1,7 & 1,9 & 3,23 & $\mathbf{L}$ \\
\hline & 44 & Terpukul jack hammer & 1,5 & 2,1 & 3,15 & $\mathbf{L}$ \\
\hline \multicolumn{7}{|c|}{ Pekerjaan Penggalian Area Utara, Selatan, dan Barat } \\
\hline \multirow[t]{2}{*}{$\begin{array}{c}\text { Perjalanan menuju / } \\
\text { dari lokasi kerja }\end{array}$} & 45 & Terguling & 1,8 & 2,6 & 4,68 & $\mathbf{M}$ \\
\hline & 46 & Tertabrak & 2,2 & 2,6 & 5,72 & $\mathbf{M}$ \\
\hline \multirow[t]{2}{*}{$\begin{array}{c}\text { Melakukan digging } \\
\text { dengan unit } \\
\text { excavator }\end{array}$} & 47 & Unit Terguling & 1,9 & 2,2 & 4,18 & $\mathbf{M}$ \\
\hline & 48 & $\begin{array}{c}\text { Tertimpa longsoran } \\
\text { material }\end{array}$ & 2,3 & 3,1 & 7,13 & $\mathbf{M}$ \\
\hline \multirow[t]{3}{*}{$\begin{array}{l}\text { Melakukan loading } \\
\text { tanah dari excavator } \\
\text { ke dumptruck }\end{array}$} & 49 & $\begin{array}{l}\text { Dump Truck tertabrak } \\
\text { bucket excavator }\end{array}$ & 1,8 & 3,5 & 6,3 & $\mathbf{M}$ \\
\hline & 50 & $\begin{array}{c}\text { Dump Truck menabrak } \\
\text { excavator }\end{array}$ & 1,8 & 3,5 & 6,3 & M \\
\hline & 51 & $\begin{array}{l}\text { unit excavator dan dump } \\
\text { truck terguling }\end{array}$ & 1,7 & 3,5 & 5,95 & $\mathbf{M}$ \\
\hline $\begin{array}{l}\text { Melakukan pushing } \\
\text { dengan unit dozer }\end{array}$ & 52 & Terguling & 2 & 2 & 4 & $\mathbf{M}$ \\
\hline \multirow[t]{4}{*}{ Operasi selesai } & 53 & Unit menggelinding & 2,1 & 1,8 & 3,78 & $\mathbf{L}$ \\
\hline & 54 & Terkilir & 2,2 & 2,1 & 4,62 & $M$ \\
\hline & 55 & $\begin{array}{l}\text { Longsor/Tertimbun } \\
\text { material tanah/beling }\end{array}$ & 2,6 & 3,2 & 8,32 & M \\
\hline & 56 & Terjatuh dalam lubang & 2,5 & 2,9 & 7,25 & M \\
\hline \multicolumn{7}{|c|}{ Pekerjaan Horizontal Drainage } \\
\hline \multirow[t]{4}{*}{$\begin{array}{l}\text { Pekerjaan } \\
\text { Pengeboran }\end{array}$} & 57 & $\begin{array}{l}\text { Mata terkena percikan } \\
\text { cairan decontaininasi }\end{array}$ & 1,8 & 1,6 & 2,88 & $\mathbf{L}$ \\
\hline & 58 & $\begin{array}{c}\text { Cedera otot Tangan } \\
\text { (keseleo) }\end{array}$ & 2,6 & 2,2 & 5,72 & $\mathbf{M}$ \\
\hline & 59 & Cedera otot pinggang & 2,6 & 2,4 & 6,24 & $\mathbf{M}$ \\
\hline & 60 & $\begin{array}{l}\text { Kaki tertimpa material } \\
\text { casing bor }\end{array}$ & 2,3 & 3 & 6,9 & M \\
\hline
\end{tabular}


Tabel 5. Hasil Penilaian Risko lanjutan

\begin{tabular}{|c|c|c|c|c|c|c|}
\hline \multicolumn{3}{|c|}{ Event Resiko } & \multicolumn{3}{|c|}{ Table Perhitungan } & \multirow[b]{2}{*}{ Kategori } \\
\hline \multirow{2}{*}{ Pekerjaan } & \multirow{2}{*}{ No } & \multirow{2}{*}{ Variable Resiko } & $\begin{array}{l}\text { Nilai Rata } \\
\text { Rata }\end{array}$ & $\begin{array}{c}\text { Nilai Rata } \\
\text { Rata }\end{array}$ & Indeks & \\
\hline & & & Frekuensi & Keparahan & Resiko & Resiko \\
\hline Instalasi Pipa & 61 & Tangan terjepit & 1,5 & 2 & 3 & $\mathbf{L}$ \\
\hline $\begin{array}{l}\text { Pengecoran slab } \\
\text { lantai, ompak dan } \\
\text { pondasi fuel tank }\end{array}$ & 62 & Terpeleset & 2 & 1,7 & 3,4 & $\mathbf{L}$ \\
\hline $\begin{array}{l}\text { Pengupasan } \\
\text { semak belukar } \\
\text { dengan Dozer }\end{array}$ & 63 & $\begin{array}{l}\text { Mata terkena material } \\
\text { grouting }\end{array}$ & 1,8 & 1,6 & 2,88 & $\mathbf{L}$ \\
\hline \multicolumn{7}{|c|}{ Pekerjaan Penimbunan Material Kaca di Area Platform } \\
\hline $\begin{array}{l}\text { Perjalanan menuju } \\
\text { / dari lokasi kerja }\end{array}$ & 65 & Terguling & 2 & 1,6 & 3,2 & $\mathbf{L}$ \\
\hline & 66 & Tertabrak & 1,9 & 2,3 & 4,37 & M \\
\hline $\begin{array}{l}\text { Melakukan digging } \\
\text { dengan unit } \\
\text { excavator }\end{array}$ & 67 & Unit Terguling & 2 & 1,7 & 3,4 & $\mathbf{L}$ \\
\hline $\begin{array}{c}\text { Mobilisasi Alat } \\
\text { Berat }\end{array}$ & 68 & $\begin{array}{c}\text { Tertimpa longsoran } \\
\text { material }\end{array}$ & 1,4 & 3,2 & 4,48 & $\mathbf{M}$ \\
\hline $\begin{array}{c}\text { Melakukan } \\
\text { pushing dengan } \\
\text { unit dozer }\end{array}$ & 69 & Terguling & 1,9 & 2,2 & 4,18 & M \\
\hline \multirow[t]{4}{*}{ Operasi selesai } & 70 & Unit menggelinding & 1,3 & 1,7 & 2,21 & $\mathbf{M}$ \\
\hline & 71 & Terkilir & 1,8 & 1,4 & 2,52 & $\mathbf{M}$ \\
\hline & 72 & $\begin{array}{l}\text { Longsor/Tertimbun } \\
\text { material tanah/beling }\end{array}$ & 2,3 & 2,4 & 5,52 & $\mathbf{M}$ \\
\hline & 73 & Terjatuh dalam lubang & 2,1 & 2,8 & 5,88 & $\mathbf{M}$ \\
\hline $\begin{array}{c}\text { Melakukan } \\
\text { pemadatan } \\
\text { dengan unit roller }\end{array}$ & 74 & Tertabrak Unit & 2,7 & 3,2 & 8,64 & $\mathbf{M}$ \\
\hline \multicolumn{7}{|c|}{ Pekerjaan Interflow Drainage } \\
\hline \multirow[t]{2}{*}{$\begin{array}{c}\text { Pekerjaan } \\
\text { Interflow Drainage }\end{array}$} & 75 & $\begin{array}{l}\text { Tertabrak bucket } \\
\text { excavator }\end{array}$ & 1,8 & 2,5 & 4,5 & $\mathbf{M}$ \\
\hline & 76 & $\begin{array}{c}\text { Terjatuh dalam lubang } \\
\text { galian }\end{array}$ & 1,9 & 3,3 & 6,27 & $\mathbf{M}$ \\
\hline \multirow[t]{2}{*}{$\begin{array}{l}\text { Membobok dinding } \\
\text { penahan tanah }\end{array}$} & 77 & Cedera otot pinggang & 2,8 & 2,3 & 6,44 & $\mathbf{M}$ \\
\hline & 78 & Debu agregat terhirup & 1,8 & 1,8 & 3,24 & L \\
\hline
\end{tabular}

\section{Pekerjaan Culvert Extension}

Extension

\begin{tabular}{|c|c|c|c|c|c|c|}
\hline $\begin{array}{l}\text { Pekerjaan Culvert } \\
\text { Extension }\end{array}$ & 79 & $\begin{array}{l}\text { Tertabrak bucket } \\
\text { excavator }\end{array}$ & 1,9 & 3,2 & 6,08 & M \\
\hline & 80 & $\begin{array}{c}\text { Terjatuh dalam lubang } \\
\text { galian }\end{array}$ & 1,8 & 3,2 & 5,76 & M \\
\hline \multirow[t]{2}{*}{$\begin{array}{c}\text { Melakukan digging } \\
\text { dengan unit } \\
\text { excavator }\end{array}$} & 81 & $\begin{array}{l}\text { Debu material debu } \\
\text { mortar terhirup }\end{array}$ & 1,8 & 1,8 & 3,24 & $\mathbf{L}$ \\
\hline & 82 & $\begin{array}{l}\text { Mata iritasi terkena } \\
\text { debu material mortar }\end{array}$ & 1,8 & 1,6 & 2,88 & $\mathbf{L}$ \\
\hline \multirow[t]{3}{*}{$\begin{array}{c}\text { Melakukan loading } \\
\text { tanah dari } \\
\text { excavator ke } \\
\text { dumptruck }\end{array}$} & 83 & Debu pasir terhirup & 1,9 & 1,5 & 2,85 & $\mathbf{L}$ \\
\hline & 84 & $\begin{array}{l}\text { Mata iritasi terkena } \\
\text { debu pasir }\end{array}$ & 1,9 & 1,8 & 3,42 & $\mathbf{L}$ \\
\hline & 85 & Gorong-gorong terjatuh & 2,6 & 1,8 & 4,68 & $\mathbf{M}$ \\
\hline $\begin{array}{c}\text { Melakukan } \\
\text { pushing dengan } \\
\text { unit dozer }\end{array}$ & 86 & Excavator terguling & 2,6 & 2,6 & 6,76 & M \\
\hline Operasi selesai & 87 & Terpental & 2,7 & 3,5 & 9,45 & M \\
\hline \multicolumn{7}{|c|}{ Pekerjaan Penimbunan Tanah Backfill (West Embankment) } \\
\hline $\begin{array}{l}\text { Pekerjaan } \\
\text { Penimbunan }\end{array}$ & 88 & $\begin{array}{c}\text { Tertabrak bucket } \\
\text { excavator }\end{array}$ & 1,5 & 3 & 4,5 & M \\
\hline
\end{tabular}


Aden Firdaus, Hazairin, Ghea Puspita Partadisastra

\begin{tabular}{|c|c|c|c|c|c|c|}
\hline \multicolumn{3}{|c|}{ Event Resiko } & \multicolumn{3}{|c|}{ Table Perhitungan } & \multirow[b]{2}{*}{ Kategori } \\
\hline \multirow{6}{*}{ Pekerjaan } & \multirow{2}{*}{ No } & \multirow{2}{*}{ Variable Resiko } & $\begin{array}{l}\text { Nilai Rata } \\
\text { Rata }\end{array}$ & $\begin{array}{c}\text { Nilai Rata } \\
\text { Rata }\end{array}$ & Indeks & \\
\hline & & & Frekuensi & Keparahan & Resiko & Resiko \\
\hline & 89 & $\begin{array}{c}\text { Terjatuh dalam lubang } \\
\text { galian }\end{array}$ & 1,6 & 3 & 4,8 & $\mathbf{M}$ \\
\hline & 90 & Debu tanah terhirup & 1,8 & 1,7 & 3,06 & $\mathbf{L}$ \\
\hline & 91 & Longsor & 2,5 & 2,5 & 6,25 & $\mathbf{M}$ \\
\hline & 92 & Slippery & 1,7 & 1,6 & 2,72 & $\mathbf{L}$ \\
\hline
\end{tabular}

\subsection{Pengendalian Risiko}

Pengendalian Risiko pada risiko tinggi yaitu dengan cara penerapan protocol Kesehatan Mengacu pada 'Protokol Pencegahan Covid-19 Di Proyek Konstruksi' yang di keluarkan Kementerian PUPR tahun 2020. Kemudian Pengendalian Risiko pada risiko sedang yaitu dengan menerapkan SOP yang baik dan benar sesuai dengan Alat berat yang digunakan, perlu juga adanya perhatian khusus terhadap APD yang digunakan oleh para pekerja untuk menghindari risiko yang timbul akibat kondisi lapangan yang merupakan bekas pembuangan limbah kaca bohlam dan TL (Limbah B3). Untuk pekerjaan yang memiliki nilai risiko rendah yang perlu diperhatikan yaitu perlunya safety talk kepada pekerja untuk memastikan pekerja tidak lalai dan mengetahui risiko dan bahaya yang di hadapi pada pekerjaan tersebut.

\section{SIMPULAN DAN SARAN}

\subsection{Simpulan}

Berdasarkan hasil penelitian Tinjauan Manajemen Risiko pada Proyek Pembangunan Bekas Daerah Pembuangan Sambirejo dapat di simpulkan bahwa:

1. Hasil dari penelitian ini di temukan 92 variabel risiko yang terdiri dari 2 risiko tinggi, 41 risiko rendah, dan 49 risiko sedang.

2. Kemungkinan risiko yang terjadi pada Proyek Pembangunan Bekas Daerah Pembuangan Sambirejo yaitu risiko penyebaran virus Covid-19 di area konstruksi, risiko kecelakaan kerja pada setiap aktivitas konstruksi, dan risiko kerusakan fasilitas umum pada tahap mobilisasi alat berat.

3. Faktor risiko yang paling mempengaruhi aktivitas pekerjaan pada proyek tersebut yaitu risiko penyebaran virus Covid-19. Masalah yang di timbulkan dari risiko tersebut dapat menyebabkan seluruh kegiatan pada proyek tersebut terhenti. Risiko ini memiliki nilai indeks risiko yang tinggi sebesar 16,45.

4. Dari hasil identifikasi risiko penangan risiko yang dilakukan adalah dengan cara menekan angka kemungkinan terjadinya dengan cara melakukan safety talk/briefing agar pekerja memahami teknis dan risiko bahaya pada pekerjan tersebut, menekan dampak keparahan yang ditimbulkan dengan cara penerapan penggunaan APD yang lengkap seperti helmet, rompi, safety shoes, sarung tangan, masker dan kacamata safety. serta mengalihkan atau menghindari risiko tersebut dengan cara berkordinasi dengan lembaga terkait untuk mengurangi dampak risiko tersebut.

\subsection{Saran}

Saran yang dapat penulis sampaikan dari penelitian Tinjauan Manajemen Risiko pada Proyek Pembangunan Bekas Daerah Pembuangan Sambirejo adalah:

5. Penulis berharap untuk mengurangi angka penyebaran Covid-19 maka sebelum dimulainya pekerjaan semua pekerja yang terlibat pada pekerjaan konstruksi fisik seperti staff lapangan dan pekerja (kepala tukang dan tukang) diwajibkan melakukan Swab Anti gen/ PCR test. Pemeriksaan kesehatan seperti Swab Anti gen/ PCR dilakukan secara berkala setiap 2 minggu sekali selama waktu kegiatan proyek berlangsung. Jika terdapat 
pekerja yang terjangkit virus Covid-19, maka pekerjaan dihentikan sementara seminimalminimalnya 14 hari kalender. Kemudian dilakukan lagi Swab Antigen/ PCR test untuk memastikan kesehatan pekerja.

6. Sebelum dilakukannya pekerjaan diharapkan kontraktor mengadakan safety talk secara berkala untuk mengingatkan pekerja akan bahaya dan risiko yang tejadi pada setiap aktivitas pekerjaan. Pastikan setiap pekerja mengerti dan memahi tahapan kegiatan dalam setiap aktivitas pekerjaan.

7. Memastikan pekerja memiliki kemampuan yang handal dan berpengalaman dalam melakukan pekerjaan yang ingin dilaksanakan.

8. Petugas K3 harus selalu siap di lapangan untuk mengurangi risiko yang telah di telaah.

9. Penelitian lanjutan dapat dilakukan untuk mengevaluasi hasil pengendalian risiko.

10. Perlu untuk selalu mengikuti perkembangan pandemic Covid-19 dan peraturan yang diberlakukan pemerintah.

\section{DAFTAR PUSTAKA}

4360, A. (2004). 3rd Edition The Australian And New Zealand Standard on Risk Management. NSW Australia: Broadleaf Capital International Pty Ltd.

Ariyanti, F. (2019, Juli 5). Manajemen, Pengertian Manajemen, Fungsi, dan Jenis Keilmuan yang Harus Kamu Tahu. Diambil kembali dari https://www.cermati.com/artikel/manajemen-pengertian-manajemen-fungsi-danjenis-keilmuan-yang-harus-kamu-tahu

E, R. (2011). UJI VALIDITAS DAN RELIABILITAS DALAM PENELITIAN EPIDEMIOLOGI KEDOKTERAN GIGI. Stomatognatic (J.K.G. Unej) Vol. 8 No. 1, 27-34.

Labombang, M. (2011). MANAJEMEN RISIKO DALAM PROYEK KONSTRUKSI. . Jurnal SMARTek, Vol. 9 No. 1, 39-46.

Nandy. (2021, Februari). Gramedia Blog. Diambil kembali dari Gramedia: https://www.gramedia.com/bestseller/manajemen/\#Pengertian_Manajemen_Secara_Umum

Ramli, S. (2010). Pedoman Praktis Manajemen Risiko dalam prespektif K3 OHS Risk Manajemen. Jakarta: Dian Rakyat.

Supriyadi, A. (2021, Maret 7). Katigaku. Diambil kembali dari https://katigaku.top/2019/02/21/statistik-angkakecelakaan-kerja-tahun-2018tertinggi-sejak-2001/

Syamsuddin. (2017). PENERAPAN FUNGSI-FUNGSI MANAJEMEN DALAM MENINGKATKAN MUTU PENDIDIKAN. Jurnal Idaarah, 66.

Wahyuni, N. (2016, Maret 10). UJI VALIDITAS DAN RELIABILITAS. Diambil kembali dari Binus: https://qmc.binus.ac.id/2014/11/01/u-j-i-v-a-l-i-d-i-t-a-s-d-a-n-u-j-i-r-e-l-i-a-b-i-l-i-t-as/

Wikipedia. (2021, Juli 22). Diambil kembali dari https://id.wikipedia.org/wiki/Pandemi_Covid19_di_Indonesia 